\title{
The disability standards and unimpeded design at Nevşehir Haci Bektas Veli Unıversity Campus*
}

\author{
Esra ÖZHANCI ${ }^{1}$, Meliha AKLIBAȘINDA ${ }^{1}$, Aslıhan TIRNAKÇII ${ }^{1}$
}

${ }^{1}$ Nevsehir Hacı Bektas Veli University, , Faculty of Engineering and Architecture, Department of Landscape Architecture, NEVŞEHİR

*This work was presented as a summary paper at International Conference on Agriculture, Forest, Food Sciences and Technologies (ICAFOF 2017).

Alınış tarihi: 15 Haziran 2017, Kabul tarihi: 07 Eylül 2017

Sorumlu yazar: Esra ÖZHANCI,e-posta:eozhanci@nevsehir.edu.tr

\begin{abstract}
The Universal Declaration of Human Rights which defines the rights of persons with disabilities with expression of "Recognizing that promoting the full participation and participation of people with disabilities in the welfare and diversity of the community and the positive contributions and obstacles they may make to human rights and fundamental freedoms contribute to their social belonging, their human, social and economic development and the reduction of poverty" and many different provisions, and emphasizes universally designed products and services to meet the specific needs of the disabled. In addition, the development of the minimum standards and guidelines for access to facilities and services that are open to the public or to public service has been materialized within the scope of accessibility. The availability of disabled people in society, the equal use of all areas can be achieved with easy access, secure, healthy, comfortable public spaces. Undoubtedly, universities should be the public spaces that offer sample design in this sense. In this study; The concept of unimpeded design and the standards of disability were examined and current status of Nevşehir Haci Bektaş Veli University Campus was assessed as being suitable for disabled standards. Positive and negative aspects were put forward and suggestions were made.
\end{abstract}

Anahtar kelimeler: Disabled standards, campus, Nevşehir

\section{Nevşehir Hacı Bektaş Veli Üniversitesi Yerleşkesinde Engelli Standartları ve Engelsiz Tasarım}

Öz

"Engellilerin toplumun refah ve çeșitliliğine yaptıkları ve yapabilecekleri olumlu katkıları ve engellileri insan haklarını ve temel özgürlükleri tam kullanmaya ve topluma tam katılmaya teșvik etmenin onların toplumsal aidiyetlerine, toplumun insani, sosyal ve ekonomik yönden kalkınmasına ve yoksulluğun azalmasına katkıda bulunacağını kabul ederek," ifadesi ve farklı çok sayıda hükümle engelli haklarını tanımlayan İnsan Hakları Evrensel Beyannamesi, engellilerin özel ihtiyaçlarını karșllamak üzere evrensel olarak tasarlanmış ürün ve hizmetler üzerinde durmuştur. Ayrıca kamuya açık veya kamu hizmetine sunulan tesis ve hizmetlere erişime ilişkin asgari standart ve rehber ilkelerin geliștirilmesi, erişebilirlik kapsamında maddelendirilmiștir. Engelli bireylerin toplum içerisinde var olabilmesi, her alanı eşit biçimde kullanabilmesi, erişimi kolay, güvenli, sağlıklı, konforlu kamusal alanlarla mümkün olabilir. Şüphesiz üniversiteler bu anlamda örnek tasarım sunan kamusal alanlar olmalıdır. Bu çalışmada; engelsiz tasarım kavramı ve engelli standartları incelenmiş, Nevşehir Hacı Bektaş Veli Üniversitesi Yerleşkesinin mevcut durumunun engelli standartlarına uygunluğu değerlendirilmiştir. Olumlu ve olumsuz yönler ortaya konarak, önerilerde bulunulmuștur.

Key words: Kohlrabi, Brassica oleraceae var. gongyloides, sowing time, mulch 


\section{Introduction}

Responsibility is to explain, verify all the actions and undertake the responsibilities of the situations that arise as a result of the actions taken by an institution (Sarıca ve Yüksel, 2012). Social responsibility is a concept that should be assessed not only in a business organization but also in a wide range of institutions from the family to the state (Yllmaz, 2006; Sarıca ve Yüksel, 2012).

It is the priority of being a contemporary society and a social state to ensure full participation in all spheres of community life by providing equal rights and opportunities without regard to physical disabilities of each individual (Berkün, 2016).

The definition of disability as a social reality changes from country to country; it can be defined as a comprehensive concept involving many healthrelated disorders. Persons with disabilities are defined as handicapped persons when they have partially or fully lost their opportunities to participate equally with others in their community life because of their disabilities. Yet, it is not the self of disability which brings person to be handicapped, it is the reaction of the society to the disability (Berkün, 2016).

It has been stated that the aim of the United Nations Convention on the Rights of Persons with Disabilities (CRPD) adopted in 2006 is to "provide, promote, protect the full and equal utilization of fundamental freedoms and all human rights of all disabled people and enhance the respect for their dignity, which originates from being human" (Anonim, 2011).

It is estimated that more than one billion people or about 15 percent of the world's population live with some kind of disability. The Global Burden of Disease Study estimated that the number of people, who have to live with disabilities between 15 and 15+ years old, is approximately 975 million (19.2\%) (Anonim, 2011).

Urgent spatial arrangements should be made so that the use of urban areas by the disabled can be carried out on an equal basis with those without disabilities. Especially, transportation for the disabled is a very important right (Firat, 2009).

World Disability Report (2011) listed the obstacles that should be handled under the title of "Overcoming obstacles and inequalities" as follows; (Anonim, 2011):: Overcoming obstacles in health care
- Overcoming obstacles in rehabilitation services

- Overcoming obstacles in support and assistance

Creating environmental conditions to provide opportunities (buildings, road systems, means of transport and principles and proposals for accessibility of information and communication technologies)

\section{- Overcoming obstacles in education}

- Overcoming obstacles in employment

The principles of the European Urban Charter (1992) under the heading "Disabilities Regarding Cities and Socio-economic Care in the City" (CE, 1992):

- $\quad$ Designing cities so that everyone can access everywhere

- Policies on the handicapped and the disabled should not be over-protective for the target groups but be integrated with society

- Cooperation and solidarity among associations representing the disabled and minorities

- $\quad$ Designing houses and workplaces in a way that is adapted to the disabled and the handicapped

- $\quad$ To make travel, communication and public transportation accessible for all people

In physical space arrangements, the basic concept is accessibility. Whether being disabled or not, every individual has the right to benefit from the public domains. Access and transportation facilities for outside or inside buildings should be ensured, and temporary or permanent bodily stresses should be taken into account.

Any structure that allows any inadequate person, especially those with wheelchairs or persons with intellectual disabilities, to enter under normal operating conditions, to walk freely in and out, and utilize all services is considered to be accessible. "The person with any inadequacy is not disabled in a space with accessibility. A solid person can also be like disabled in a place that is not accessible." (Scherrer, 2001).

According to the Construction Zoning Law (No. 3194), public domains must comply with TSI standards. Within the scope of the standards prepared and adopted by the Turkish Standards Institute (TSI), related with disabilities, TS 12576, which was enacted in April, 1999, was updated in 
2012, and excluded the statement of "the disabled" and covered the design rules for all pedestrians. The rules are listed under the name of "Urban RoadsDesign Rules for Structural Measures and Markings for Accessibility in Sidewalks and Pedestrian Crossings."

The purpose of this study is to evaluate the situation of universities within the contexts of being easy to access, safe, healthy, comfortable public places with the idea that the disabled can exist in society and use all fields equally. From this point of view, the current situation of Nevsehir Haci Bektaş Veli University campus was evaluated in terms of the conformity with the standards of the disabled. Analyzes and evaluations carried out in the study have considered that the university is a "young" university and that the construction works are still continuing. However, evaluations may reveal the overlooked faulty practices; and if they are taken into consideration, they may give the practitioners a chance to intervene while there is still time.

\section{Materials and Methods}

\section{Material}

The material of the study is the open areas of Nevşehir Hacı Bektaş Veli University Central Campus (Figure 1). Nevsehir Hacı Bektaş Veli University, which has had more than 19 thousand students since 2016, built on May 17, 2007. The university continues its scientific activities in 6 different settlements, one of which is the main campus, and has 7 faculties, 7 vocational schools, 3 academies, 3 institutes and 8 research and application centers (Anonim, 2017).

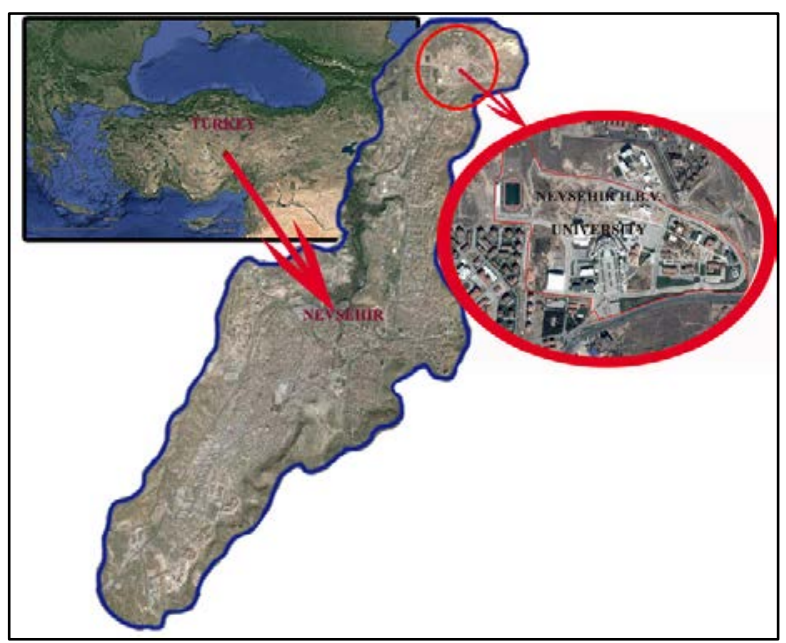

Figure 1. The location of the Study area.

The campus area with a green area of $134.450 \mathrm{~m}^{2}$ was considered as two separate parts in the study, and the sections of the area which are still under construction, and the landscaping practices were excluded from the evaluation. The first part consists of faculties/academies and institutions and service buildings located in the eastern part of the north axis of the campus. These buildings are; Faculty of Economics and Administrative Sciences, University of Science and Technology, Institute of Social Sciences, Application and Research Centers Building, Health Services Vocational School, Semra and Vefa School of Health Academy, Faculty of Tourism, Vocational School, Central Cafeteria and Service Buildings. All these buildings are located in the same area and spread out in a large square where pedestrian paths and various landscaping works are done. The second part consists of faculties/academies, institutions and service buildings located on the western side of the university. These buildings are; Rectorate Building, Faculty of Science and Literature, Faculty of Education, Foreign Language Academy, Congress Center, Faculty of Engineering and Architecture, Science and Technology App. And Res. Center, Indoor and Outdoor Sports Halls and Nursery. This part represents a larger area than the eastern part. However, since the buildings works are still continuing, the whole area has not been evaluated. The square and ceremony area to the south of the area forms a focal point, but does not hit an organic bond as far as the east.

\section{Method}

Data collection, analysis and synthesis methods were used in the study. Evaluation of the standard criteria were determined according to previous studies (Kansu, 2001; Ören, 2015; Çivici ve Gönen, 2015; Demiroğlu vd., 2016) and TS 12576.

The campus area was examined in two parts, and the area was classified in terms of the landscaping elements and analyzed under these headings (Ören, 2015; Çivici ve Gönen, 2015);

- Transportation items (pedestrian roads, ramps, stairs, floor materials)

- $\quad$ Building entrances

- Information boards and panels

- $\quad$ Lighting items

- Green elements

- Water issues

- Accessory items

- Parking lots 


\section{Results}

\section{Basic standards}

\section{In terms of transportation elements}

Regulations on pedestrian roads in public outdoor areas must first be adequate for all users, and they must be designed in such an accessible way without alienation. This is shaped according to several factors such as the width of the road, the material of the floor, the presence of the disabled roads and its place and continuity. The ground covering should preserve the uniformity and integrity and must be at the same height with the road surface. The floor covering should not be slippery. The floor covering should not create bumps or pits on pedestrian paths and should not move when stepped on them, and after all, it should be reliable for all (TS 12576). Walkways should have Sensible Walking Surface (TS 12576), safe movement; and also, transportation should be provided. Users must be informed with different textured surfaces (TS ISO 23599) especially for entries, turns and barriers.

The minimum width required for wheelchair users and for the ones who has the limitation of movement ability to be able to use pedestrian paths is $150 \mathrm{~cm}$. Any element on the road should not constrict this width. According to TS 12576 Standard, the minimum space required for wheelchair users to rotate $90 \mathrm{o}$ and $180 \mathrm{o}$ is $150 \times 150 \mathrm{~cm} ; 150 \times 200 \mathrm{~cm}$ for U-turn; 110x122 cm for turning around an obstacle. The roads should not be slippery and should not create a danger of falling.

Since stairs are a great obstacle to the accessibility for the disabilities, stairs should be avoided as much as possible in the roads. There must be a ramp in entrances and sloped areas where there is a need for stairs. Ramps may be placed next to stairs. According to the standard; ramp inclines should be up to $5 \%$ and the width should be at least $100 \mathrm{~cm}$. According to TS 12576 Standard; the width of the stairs in the roads should be at least $180 \mathrm{~cm}$. All of the steps must be at equal height. The step width should be at least $30 \mathrm{~cm}$ and the step height must be $15 \mathrm{~cm}$.

If the width of the stairs is more than $300 \mathrm{~cm}$, a safety rail must be placed on the center, too. The rails at the beginning and at the end of the stairs should be bent in a semicircle so that the tips of them do not lead to any accidents (TS 9111).

Also, the pavement height is maximum $15 \mathrm{~cm}$ in TSI standard. In an attempt to not bother the disabled persons from height differences on the sidewalks, slopes should be provided in such roads so that they can move comfortably and easily.

\section{Building entrances}

Building entrances must be designed properly from the functional point of view as well as from the aesthetic point of view. It includes topics like the heights and widths of the stairs, the use of different coverings on floor and slip-coat of the floor, the use of ramps and the use of railings in wide stairs.

According to the standard, the main entrances of all commercial, administrative and residential public buildings must be made unimpeded from the pedestrian walkway. Building entrances must be made from hard non-slip material and these entrances must be well-lit.

Each edge of the stairs must be coated with $2,5 \mathrm{~cm}$ width contrasting color non-slip strips. At the beginning and at the end of the stairs there must be an "alerting surface" (TS ISO 23599).

\section{Information boards and panels}

Information boards are very important in terms of user guidance and healthy navigation. At the same time, however, they should not narrow or obstruct the user's perceptional angle. According to TS 12576 Standard, the items should be placed in such a way that they do not block the pedestrian crossing, and they should not be on HYY. Those placed on the road should not narrow the road moving area. The boards lying on the road or on the road must be at least 220 $\mathrm{cm}$ in height. These boards and panels must contain contrasting colors to be noticed. The signs and panels used by the visually impaired persons must be at least $70 \mathrm{~cm}$ above the floor and must have Braille on it.

\section{Lighting items}

Lighting is the basic requirement of an open area. Undoubtedly, on university campuses where the night-time use is possible, the safe movement of students and faculty members should be provided. Lighting is the first step in security perception.

According to 12576 Standard, the lighting elements should be placed in such a way as not to block passing, and the width and the movement area of the roads should not be narrowed. The lighting elements on the pedestrian path or located on the road must have a height of at least $220 \mathrm{~cm}$ from the ground. The lighting on the road should be in contrasting colors, not on the HYY, so that to be noticed by those with low vision. They should not have sharp, protruding 
edges; also, bolt ends and electrical parts should not remain uncovered.

\section{Green issues}

Vegetation elements are the basic issues of ecological aspects of open areas. However, due to great variety both in size and quality, the direction of design is important in terms of user safety and comfort.

According to the standard, green stuff should not be placed on the pedestrian route unless they are mandatory, they should be placed on the edges so as not to obstruct the passing, and there should be no green items on HYY. Pots, trees, plant arrangements should not narrow the road width and area of motion, and such items should be painted with noticeable contrasting colors. The branch height of the plants should be at least $220 \mathrm{~cm}$. The plants whose products may make the road slippery or the thorny plants damaging the passersby should not be planted near the ramp and the stairs, also, they should not have sharp and protruding pieces.

\section{Water issues}

The most vibrant and dynamic element of the landscaping is water. The use of this element, which increases the level of visual quality and naturalness of the place, provides qualification. But of course it must be applied in a proper way. These items should be placed on the edges so as not to block passing, should not narrow the path width and the area of motion and should not be on HYY. They should be painted in contrasting colors. The items like lake and water canal which are next to the road or may create a danger of falling must have noticeable edges at least $10 \mathrm{~cm}$ high or should be separated from the road by fence, stone and grass areas. Fountains and waterfalls should not splash water on the way.

\section{Accessory items}

Shadow-aimed pergolas and summerhouses should be placed in accessible spots for easy access of users, especially for people with disabilities. Entries must be wide and may have a moving area depended on the design model. The wheelchair area should be considered, and sharp and protruding materials should not be used. The tables should be placed in appropriate places so that it can be easily reached by all. The tables should not narrow the width of the pedestrian path and the range of motion, also, they should not have sharp, protruding edged designs. The min height of the table should be $86 \mathrm{~cm}$; bottom height, $75 \mathrm{~cm}$; foot space, $60 \mathrm{~cm}$; and the movement area in front of the table, $100 \mathrm{~cm}$. According to the standard, the sitting benches must be on the side of the road, and must not make passing difficult and narrow the road width and area of motion. A chair space with a width of at least $90 \mathrm{~cm}$ and a height of $120 \mathrm{~cm}$ must be left on the edge of the bench for the disabled to be able to sit with their friends. In the banks, the back must be $45 \mathrm{~cm}$; the height, $41-46 \mathrm{~cm}$; arm height, $15 \mathrm{~cm}$; and the width of the bench, between 36 and $46 \mathrm{~cm}$. There must not be sharp or protruding pieces. The trash cans should be placed properly to make everyone reach easily including wheelchair users. According to the standard, the height of the trash must be between 90 and $120 \mathrm{~cm}$. Boxes must be painted in contrasting colors. There must not be sharp and edged places in the trash cans.

\section{Parking lots}

In general, in parking lots or in district and public car parks, $5 \%$ of the parking spaces must be separated for the disabled. Parking lots for the disabled must not be far from the entrance ramp more than 30 meters (TS 9111).

\section{Current status of the settlement in terms of the disabled standards}

\section{Transportation}

Andesite stone has been generally used on pedestrian routes. Although these floors are new, deterioration has been observed. In the past, basalt stone strips were used to design the floor. However, it has been observed that these black grounds have a relatively high slipperiness, and therefore, can create danger. In addition, designs have been made with strips by using granite keystone. In the same way, this practice is also at risk for walking safety due to the gaps (Figure 2). In the areas where the practice is still continuing, there are exposed infrastructure elements and ground defects in certain places.

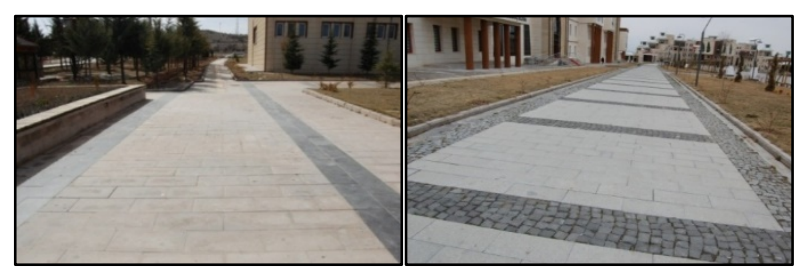

Figure 2. Pedestrian paths floor covering.

In most of the settlement, the HYY application, which circulates in the form of a ring, was carried out in a systematic manner. In addition, the UY applications that completed these roads were also used, emphasizing entry, return and obstacle (Figure 3). 


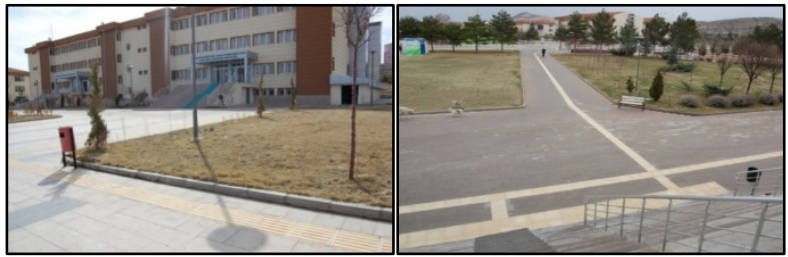

Figure 3. There is a systematic HYY application on campus.

There are no HYY applications in the two squares used for only ceremonial aims or etc. There are HYYs for use around the main square, but there is no navigation to the central dining hall (Figure 4).

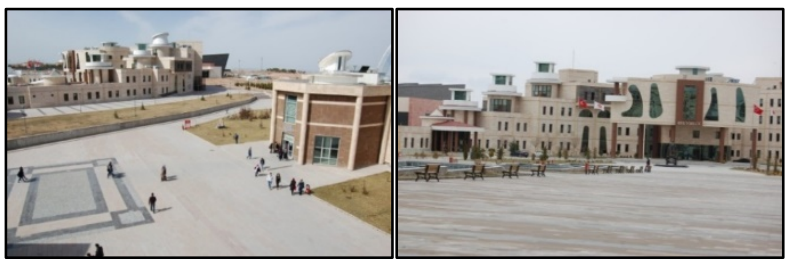

Figure 4. Two central squares are deprived of a road for the use of the disabled.

However, various mistakes were observed in practice. The distance between the borders of HYY is mostly $30 \mathrm{~cm}$. This explains the dangers of the disabled person more or less; the walking path presented in a narrow area increases the likelihood of injury due to an accident with a small loss of balance. Moreover, it has been observed that many of the equipment and elements are directly or partly intersected in this way. For example, it is observed that while the garbage cans are located at the arm's edge, the bole of the present tree is in this way at one point. Or the branches of the bushes group can completely prevent walking. Apart from all the inconvenient conditions and effects, the disabled user is furthered by being pushed to the edge even when the appropriate area is available (Figure 5).

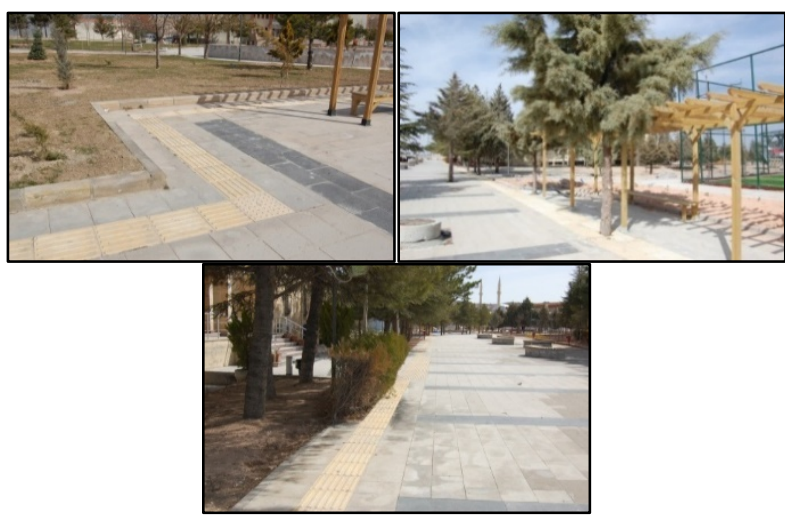

Figure 5. The obstacles on HYY routes make the application unsafe.
In addition, no HYY application was carried out on the informal walkways located in the eastern part. The allee effect used in the landscaping of this part of the road was seen as misapplication not only for disabled but also for all users. In addition, there were also some problems of continuity of HYYs (Figure 6).

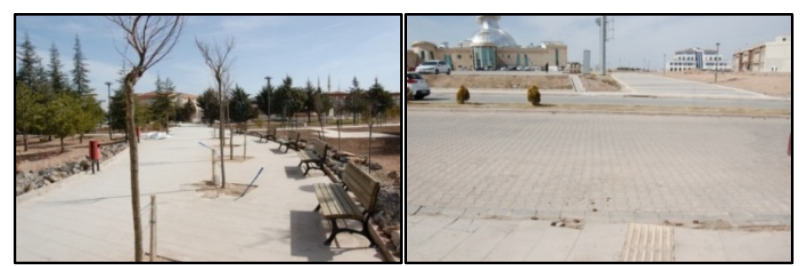

Figure 6. There are deficiencies in HYY applications.

Stairs and ramps are generally ergonomic in terms of slope grade, width and height. In places where there is a need for stairs, ramp has been placed. Pavementto-road transitions are connected with appropriate inclines, facilitating movement (Figure 7).

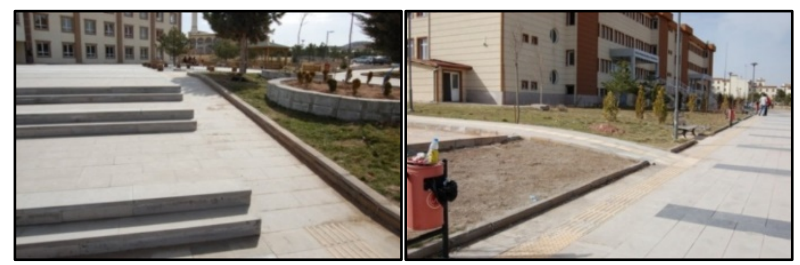

Figure 7. Ramp applications provide flexibility of movement.

However, in some places, the use of the ramp was overlooked when high stairs were used. There are some places where railing is not applied or applied to stairs which has more than $300 \mathrm{~cm}$ width. Pavement heights are also suitable for the standards and not too much high. However, the height of some pavement applications is a little bit challenging in terms of user ergonomics. In addition to this, the use of the ramp was overlooked in some pavement-toroad descents, and no proper slope was given (Figure 8).

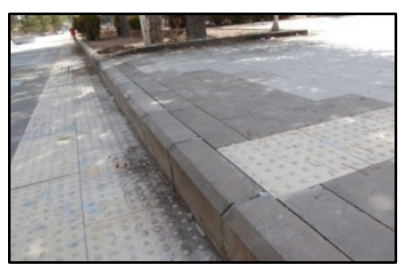

Figure 8. The pavement height should not exceed $15 \mathrm{~cm}$.

\section{Building entrances}

While some of the buildings in the campus allow entrance to the ground with a zero elevation (Figure 9), some of the high entrances in which many steps are located are noteworthy. These stairs are emphasized with the UY footsteps. In addition, in these entrances, the application of the railing was 
also occasionally encountered in stairway widths, but no widespread application was observed.

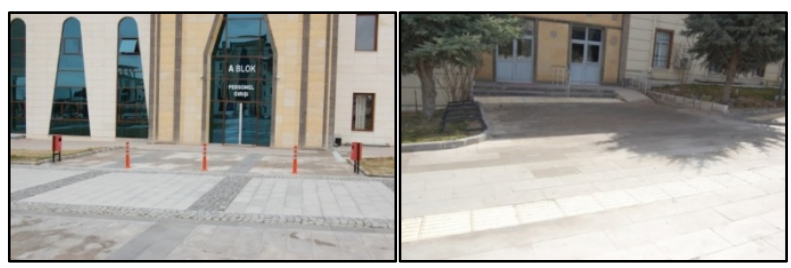

Figure 9. Some buildings have the same floor entries with the floor.

It has been observed that sufficient light is provided by the lighting elements. However, there are only a few places where slip-resistant strips are found. In some stairway entrances and in the sections leading to the entrance gate; curved stair carpets are applied (Figure 10).

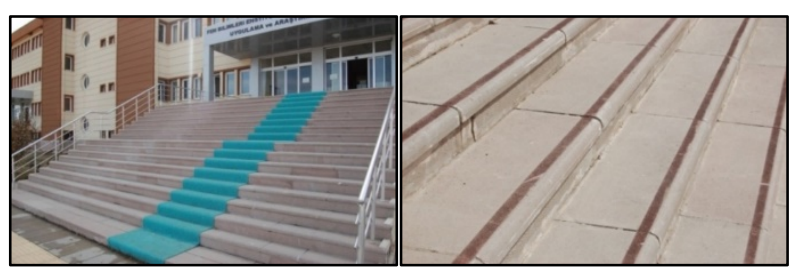

Figure 10. Stairs applications are in different types.

Ramps in these high stairway entrances are undoubtedly in a crucial need. It was observed that the ramp application was not uniform, some buildings have ramps in the main entrances, and the some have in the secondary. In the few buildings without ramps, another side door and elevator gate are located. However, these elevators are not actively used (Figure 11).

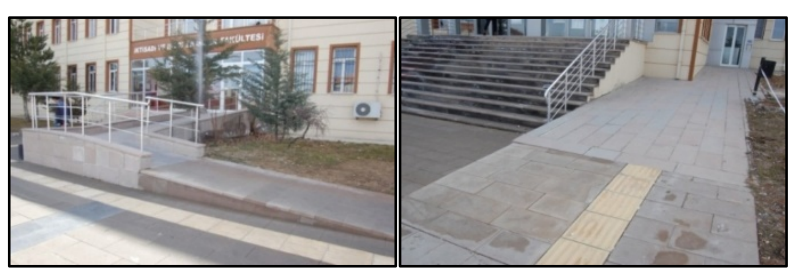

Figure 11. Ramp and elevator applications.

\section{Information boards and panels}

Information boards pointing to faculty/college/institute, etc. are included. There is also an electronic billboard and advertising/ poster billboard in the area. These boards and panels are correctly applied in terms of height and position, they are designed easily for the perception of the user, and do not create any obstruction within the area and do not narrow the HYY and the road movement area. However, Braille surfaces were not used for visually impaired (Figure 12).

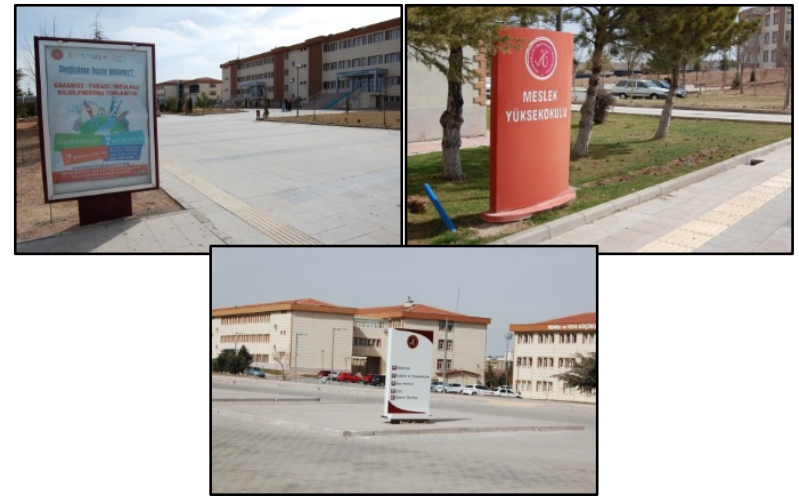

Figure 12. Board and panel applications.

\section{Lighting items}

Lighting system applications are generally sufficient and efficient. Illuminations are usually located in green grass areas or in refuges. On the main roads, high and wide areas, the lighting is effective; in internal areas, about $4 \mathrm{~m}$ high illuminations are used. There are no illuminations on the hiking trails and no color applications are made. In addition, in the center of the hard floor arrangement, spotlights placed on top cover systems are used, resulting in a strong light effect (Figure 13).

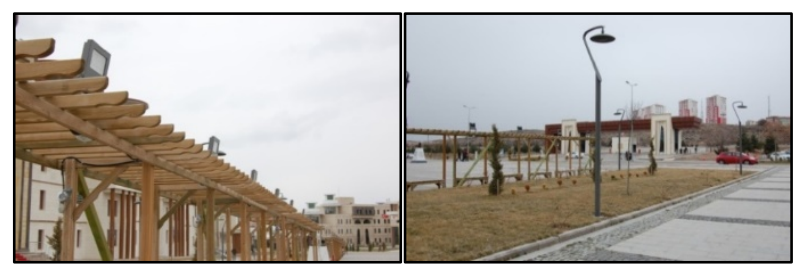

Figure 13. Illuminations in different types increase vision.

\section{Green issues}

According to the standard, green stuff should not be on the pedestrian route unless they are mandatory, they should be placed on the edges, and there should be no green items on HYY.

Although most of the campus arrangements seem appropriate in terms of standards, some plantation practices have been carried out on pedestrian paths, and these practices have formed obstacles to walking as emphasized earlier. Some of the plant applications in the roadside grass area bring restrictions due to their height and diameter properties. In fact, as mentioned in the ransportation section, the tree bole is located on HYY.

\section{Water issues}

There are existing and currently implemented water surfaces within the university campus. These surfaces are located on the hard ground and in the grass area, and the pools are designed higher than 
the grounds, so the danger is avoided. These pools, which are easy to perceive regarding material selection, do not narrow the pedestrian movement area (Figure 14).

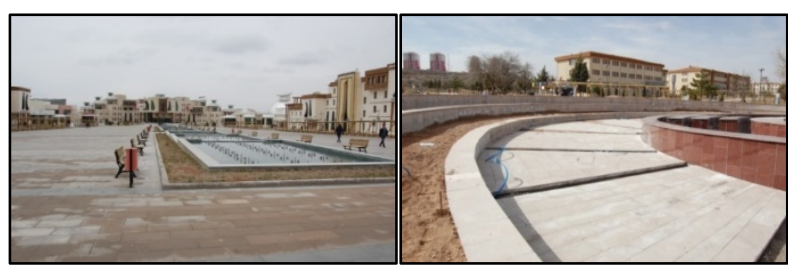

Figure 14. The water surface in the campus is unobstructed.

\section{Accessory items}

A large number of covered or latched seating elements are located on campus in the form of two types (summerhouses, and wooden pergola). These elements are in different size and quality, and are located in active use routes of the students, and serve as places where students can spend their free time and perform activities (Figure 15).

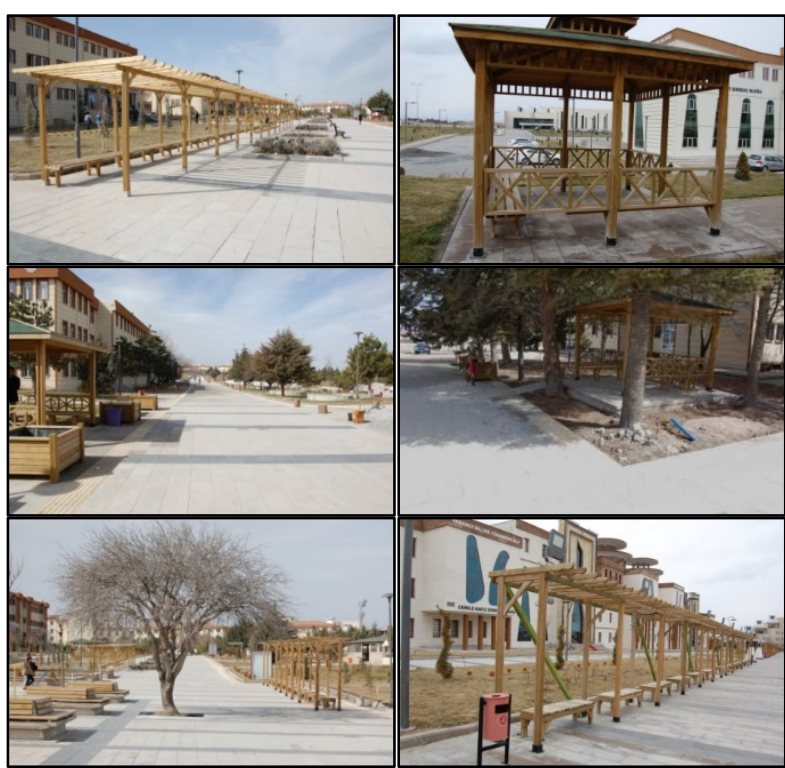

Figure 15. Top-covered elements at the settlement are widely used.

When we consider these top-covered elements in terms of landscaping design principles, we see that they have a number of erroneous design features like not providing enough shadow in such a sunny city like Nevşehir and creating a monotony. However, this study will not focus on these deficiencies.

Pergolas and summerhouses must be accessible in terms of easy access of the users, and have wide entrance and motion area in the direction of the model. From this point of view, there are some applications which have a narrow entrance and no ramp usage. While it is possible to connect them with HYY, this is not applied in some areas (Figure 16).

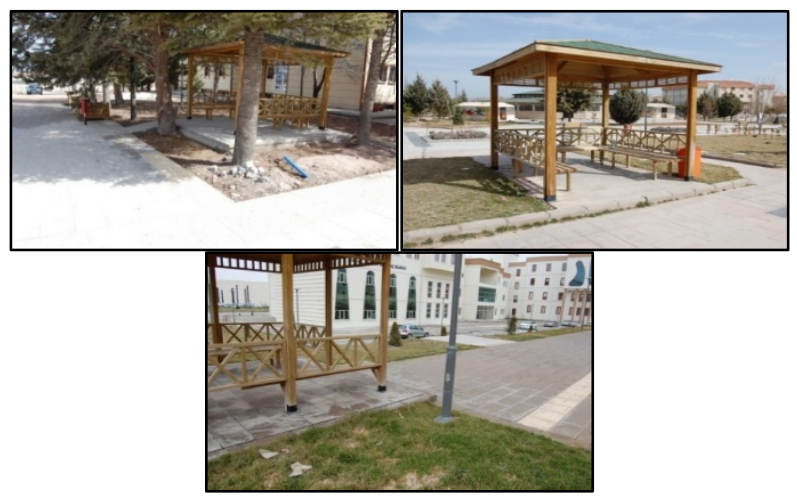

Figure 16. Top-covered applications have some deficiencies.

On the informal walkways, iron profile top-covering systems combined with ivy are used as corridors. These items are not dangerous or form any other obstacles, but the tree bole and the root area that cut through these corridors greatly narrow the walking area (Figure 17).

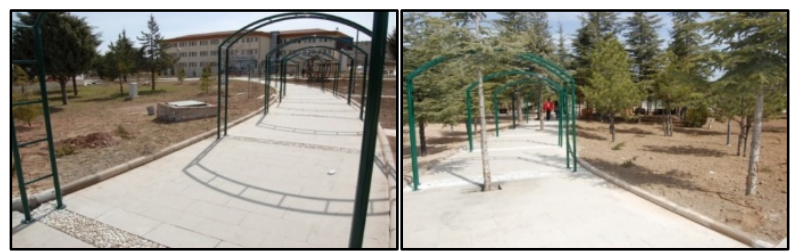

Figure 17. Top-covered application on informal roads.

In accordance with the standard, the sitting benches have been used on the road sides, these elements do not make passing difficult, and do not narrow the road width and movement area. Moreover, seating units have also been used on the appropriate floor size and the passing is not obstructed in there, too. These units are designed without obstacles in terms of their qualities and size. There are chair spaces around the benches for people with disabilities to sit with their friends. No sharp or protruding pieces are seen (Figure 18).

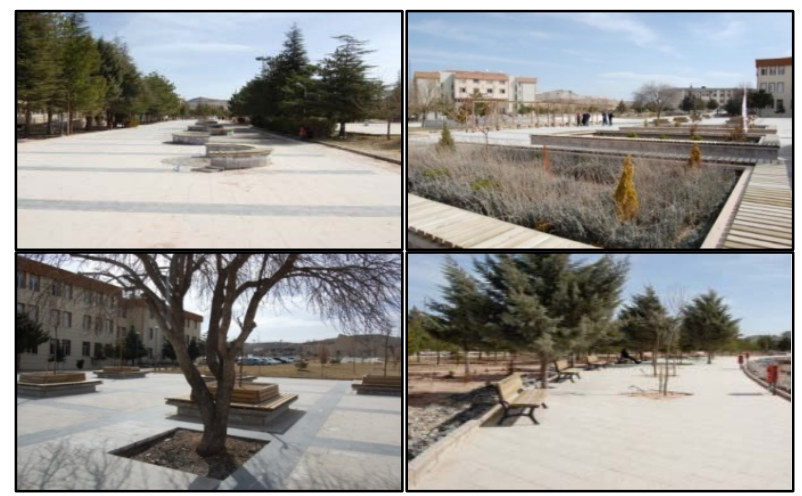

Figure 18. There are many seating units in the campus. 
Garbage cans used in the campus are located where everyone can reach including wheelchair users. The height, color and material properties are ideal for unobstructed use.

\section{Parking lots}

In university campus, there are parking lots of different size near education and service buildings and university entrance. In the central parking lot, which is the largest of these parking lots, the disabled user areas are identified with lines and signs, the closest car parks are selected and their sizes are applied in this direction (Figure 19). However, it is not possible to see such a clear and healthy application in other parking lots.

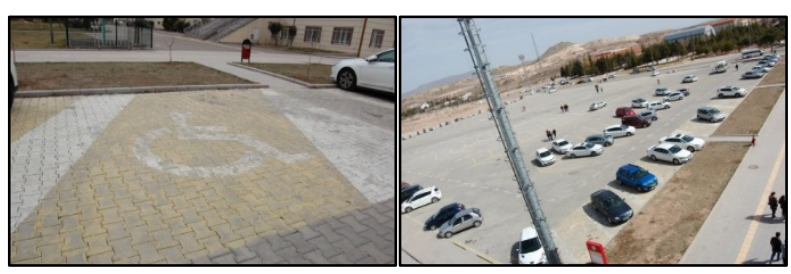

Figure 19. The central parking lot of the settlement is unobstructed.

\section{Result}

The number of people with disabilities is increasing. The reason for it is mostly the aging of population. These people are at high risk of disability; and chronic health problems related to disability are increasing worldwide (Anonim, 2011).

No doubt, every building and institution needs to work specifically for the good of the disabled in its own way and put it into the system. The World Health Organization lists the basic conditions for academic institutions, and by obeying these conditions, the obstacles may be overcome in the acceptance areas of such institutions; and the participation of the students or employees with disabilities in the universities and vocational education courses can include proper information on human rights principles on disability. Furthermore, researches can be conducted on the lives of the disabled people and the obstacles they face by consulting their organizations (Anonim, 2011).

Beyond the disabled users, in all public area plans and designs, the rights and demands of pedestrians should be placed first. With the opportunities provided by mechanics and technology, the structure of society, which is actually self-imprisoned, shows itself very clearly on the street. People nowadays walk on the road with devices like telephone, music player etc., and talk to themselves and not hear voices. Thus, in such a social structure, several accidents might happen increasingly.

Such a self-blocking structure makes both pedestrian and recreational applications and driver sensitivity more important in traffic flow. The precautions taken against any accidents in case a pedestrian steps to the road in the European countries should also be applied in our country, and the individuals should be trained in this direction. Pedestrians should be aware of the fact that traffic is not only made up of vehicles or the dangers originating from them and they should be conscious about their rights. Especially in areas where pedestrian activity is high, such as university campuses, vehicle users must show sensitivity and give particular importance to the safety of pedestrians.

Accessibility can be likened to a chain, when a single ring of chain is missing, the entire chain is broken and accessibility will disappear (Scherrer, 2001). While there are disability-oriented applications within Nevşehir Hacı Bektaş Veli University Central Campus, there are no barrier-free design practices applied to pedestrian roads and bus stops in the neighborhood of the campus entrance. Undoubtedly, this situation considers the productivity of an application that is not continuous and extensive. People do not become disabled at the campus entrance, living conditions need to be adapted from the moment they leave home.

Facilities for the use of the disabled are weak in passive recreational or activity areas (ceremonies, concerts) in the campus. Disabled persons' socializing opportunities are getting narrowed.

From the point of pavement arrangements, the first way to provide pedestrian safety is a proper space organization. The separation of the road connection of the pavement by a green bumper corridor will provide both aesthetic and ecological contribution, as well as fulfilling its functions in terms of safety of all pedestrians. While it is possible to apply this practice in such a new settlement, no likewise design was encountered.

It is possible to evaluate Nevşehir Hacı Bektaş Veli University campus as a public place where user ergonomics are taken into consideration and where the design applications without obstacles can be seen. The work done is promising and exemplary. However, applications should be audited at every stage, objective assessments should be made to eliminate the deficiencies, and modern applications should be followed in order to apply more ideal ones. 
Indeed, the teaching of our own culture is in this direction. Human-oriented, ecological sensitivities will undoubtedly be successful. This, of course, is only possible if people increase their behavioral skills based on tolerance and empathy. Community involvement and collective behavior also require this.

"Disability does not have to be an obstacle for success. I spent almost all of my adult life with motor neuron disease. But this disease did not prevent me from having an important career in astrophysics and having a happy family"

Professor Stephen W. Hawking

\section{Kaynaklar}

Anonim, 2011. Dünya Engellilik Raporu Yönetici özeti. Dünya Sağllk Örgütü.

Anonim, 2017. Nevşehir Hacı Bektaş Veli Üniversitesi Resmi Web Sitesi. https://www.nevsehir.edu.tr/tr /tarihce, Erișim: 9.3.2017.

Berkün, S., 2016. Avrupa Kentsel Şartı'nın Kentlerdeki Özürlü ve Sosyo-Ekonomik Bakımdan Engellilere Yönelik İlkeleri ve Bursa Kentinde Kamu Kurum ve Kuruluşlarının Erișilebilirliği. Aksaray Üniversitesi İktisadi ve İdari Bilimler Fakültesi Dergisi, 8 (1):6172 .

Council of Europe,1992. European Urban Charter-Charter without the status of a convention, A. The European Declaration of Urban Rights https://wcd.coe.int/ ViewDoc.jsp?p=\&id=887405\&direct=true Erişim: 5.1.2017.
Çivici, T., Gönen, D., 2015. Balıkesir Üniversitesi Çağıș Yerleşkesinin Bedensel Engelli Öğrencilerin Sosyal Alanlara Ulaşabilirliğinin Değerlendirilmesi. Süleyman Demirel Üniversitesi Mühendislik Bilimleri ve Tasarım Dergisi, 3(3): 639-646.

Demiroğlu, D., Çoban, A., Özgür, D., 2016. Engelli Bireylerin Üniversite Yerleşkelerinde Ortak Mekânları Kullanabilmeleri Üzerine Örnek Bir Araştırma: Kilis 7 Aralık Üniversitesi Merkez Yerleşkesi. İnönü Üniversitesi Sanat Ve Tasarım Dergisi, 6 (13): 91108

Firat, S. 2009. Engelsiz Bir Kent Tasarlamada Yerel Politikaların Önemi. Toplum ve Sosyal Hizmet Dergisi, 20 (2).

Kansu, R., 2001. Ulaşılabilirlik ve yasalar. Herkes İçin Ulaşılabilirlik Seminer Notları, İstanbul Omurilik Felçlileri Derneği Yayını.

Ören, Ö., 2015. Kent Parklarının Engelli Standartları Açısından Değerlendirilmesi (Recep Yazıcıoğlu ve Adalet Parkları-Denizli). T.C. Pamukkale Üniversitesi Sosyal Bilimler Enstitüsü Dönem Projesi, Siyaset Bilimi ve Kamu Yönetimi Anabilim Dalı, Denizli.

Sarıca, Y.P.S., Yüksel, E., 2012. Yerel Yönetimlerde Sosyal Sorumluluk Projesi Uygulaması Olarak Sosyal Hayata Katılım: Engelsiz Yaşam. Çalışma İlişkileri Dergisi, 3 (1): 48-66

Scherrer, V. 2001. Neden Ulaşılabilirlik Hakkında Düşünmeliyiz. Herkes İçin Ulaşllabilirlik Seminer Notları, İstanbul Omurilik Felçlileri Derneği Yayını.

Yılmaz, K., 2006. Örgütlerin Sosyal Sorumlukları: Kavramsal Bir Çözümleme. M. Akif Ersoy Üniversitesi, Eğitim Fakültesi Dergisi, 12: 65-79. 